Elaine Jeffreys and Pan Wang (2018) 'Pathways to Legalizing Same-Sex Marriage in China and Taiwan: Globalization and "Chinese Values', in B. Winter, M. Forest and R. Sénac (eds), Global Perspectives on Same-Sex Marriage: A Neo-Institutional Approach, Cham: Palgrave Macmillan, pp. 197-220. Author Copy, 28 August 2017.

\title{
Pathways to Legalizing Same-Sex Marriage in China and Taiwan: Globalization and "Chinese Values"
}

Elaine Jeffreys and Pan Wang

University of Technology Sydney

\begin{abstract}
What might motivate the People's Republic of China (PRC) to recognize same-sex marriage and what has spurred Taiwan's Constitutional Court to instruct the Taiwan parliament to legalize same-sex marriage? This chapter traces the emergence of advocacy for marriage equality in the context of two different and evolving political systems. Taiwan looks set to become the first Asian country to legalize same-sex marriage as the result of an active LGBT movement, multiparty strategizing and government efforts to differentiate Taiwan from China in international arenas. But the exact nature of such legislation may be influenced by public protest against marriage equality on the grounds that it will undermine religious and traditional Chinese family values. While domestic pressure for marriage equality is a more recent and restrained phenomenon in China, the rise of the PRC as a global superpower and the current administration's emphasis on promoting "Chinese" and core socialist values may eventually enable the recognition of same-sex marriage equality by government fiat.
\end{abstract}

\section{Introduction}

This chapter compares the historical, political, social, and discursive factors contributing to and preventing equal recognition of same-sex partnerships in the People's Republic of China (PRC) and Taiwan. The populations and cultures of China and Taiwan are generally described in homogeneous terms as "Chinese." But they have had different systems of political and social organization since 1949, when the Chinese Communist Party (CCP) won the Chinese civil war and founded the PRC, and the rival Nationalist Party fled across the 
Elaine Jeffreys and Pan Wang (2018) 'Pathways to Legalizing Same-Sex Marriage in China and Taiwan: Globalization and "Chinese Values', in B. Winter, M. Forest and R. Sénac (eds), Global Perspectives on Same-Sex Marriage: A Neo-Institutional Approach, Cham: Palgrave Macmillan, pp. 197-220. Author Copy, 28 August 2017.

Formosa Strait to the island of Taiwan where it established an authoritarian regime called the Republic of China. This situation created two "Chinas", with both political entities claiming to be the sole and legitimate representative of "China."

Despite the subsequent opening-up of both economies to globalizing forces, the PRC retains a one-party ruling system, while Taiwan became a multi-party state with a popularly-elected president in 1996 and had an active LGBT movement by the early 2000s. In the PRC, state controls over the media and social organizations ensured that LGBT issues did not become a major feature of public discourse until after the 2000s. Yet, in 2015-2016, a retired CCP official and father of a gay son petitioned the National People's Congress (the PRC's legislature) to support families by recognizing same-sex marriage, and a landmark same-sex marriage case was heard and rejected by the Chinese courts (Phillips 2016; Zhang 2015).

In Taiwan, the Constitutional Court ruled on 24 May 2017 that laws preventing same-sex marriage are unconstitutional because they violate citizen rights to equality, and instructed the Taiwan parliament to amend or enact laws within two years or the legislation will change by default ("Victory at last" 2017). Taiwan is thus set to become the first country in Asia to recognize same-sex marriage, although the exact nature of such legislation may be influenced by public protest against marriage equality on the grounds that it will undermine religious and traditional Chinese family values.

What might motivate the PRC government to recognize same-sex marriage and what has spurred Taiwan's Constitutional Court to instruct the Taiwan parliament to legalize same-sex marriage? We answer these questions via case studies of the PRC and Taiwan respectively. We explain why homosexuality was an "invisible" phenomenon in both countries until recently, and trace the emergence of advocacy for marriage equality in the context of two different and evolving political systems. We attribute Taiwan's path to becoming the first country in Asia to legalize same-sex marriage to the combination of an active LGBT movement, multiparty strategizing, and government efforts to differentiate Taiwan from the PRC in international arenas. At the same time, the rise of the PRC as a global superpower, the lack of civil society opposition to same-sex marriage in that country, and the current administration's emphasis on promoting "Chinese" and core socialist values may, perhaps 
Elaine Jeffreys and Pan Wang (2018) 'Pathways to Legalizing Same-Sex Marriage in China and Taiwan: Globalization and "Chinese Values', in B. Winter, M. Forest and R. Sénac (eds), Global Perspectives on Same-Sex Marriage: A Neo-Institutional Approach, Cham: Palgrave Macmillan, pp. 197-220. Author Copy, 28 August 2017.

surprisingly, enable the "peaceful" recognition of marriage equality in China by government fiat.

\section{Case Study 1: China}

What might motivate the PRC government to institutionalize same-sex marriage and endorse what is upheld in many western liberal-democratic societies as a progressive human rights policy? Writing of the 2000s, Timothy Hildebrandt (2011) provided three possible answers: (1) domestic pressure from LGBT organizations; (2) international pressure; and (3) tactical decision-making by an authoritarian government aiming to improve its international reputation. The first two answers draw on the historical experience of western social movements to obtain legal rights for LGBT people. This history involved struggles for the decriminalization of homosexuality, anti-discrimination legislation, and legal recognition of same-sex partnerships respectively, and often with reference to international human rights' conventions (UNDP and USAID 2014, 23). The situation in China is different.

Homosexuality is not criminalized in the PRC, but the nature of the Party-state has ensured that there is no national political discourse on LGBT matters, no protective national laws and that no specific Ministry has responsibility for issues relating to sexual orientation and gender identity (UNDP and USAID 2014, 11). Media censorship of sex-related content and controls on social organizations have further limited public advocacy on LGBT matters, and the PRC government is renowned for only talking about human rights on its own terms. Hence Hildebrandt $(2011,1313)$ concludes that marriage equality by government fiat is the most likely option, but "the right to marry will do little to challenge the larger social pressures that make life difficult for LGBT Chinese."

\section{Background}

From 1949 until the 1980s, homosexually was a virtually "invisible" practice in the PRC, flowing from the early CCP's adoption of centralized economic planning, and promotion of free choice, monogamous (heterosexual) marriage. Nationalization of industry and curtailment of the monetary economy meant that the Party-state provided citizen-workers with employment, housing, and the necessities of everyday life, which had the corollary 
Elaine Jeffreys and Pan Wang (2018) 'Pathways to Legalizing Same-Sex Marriage in China and Taiwan: Globalization and "Chinese Values', in B. Winter, M. Forest and R. Sénac (eds), Global Perspectives on Same-Sex Marriage: A Neo-Institutional Approach, Cham: Palgrave Macmillan, pp. 197-220. Author Copy, 28 August 2017.

effect of restricting the spaces for same-sex behaviours by limiting both population mobility and the kinds of venues in which individuals could engage in anonymous or private behaviours (Jeffreys and Yu 2015, 18-21). The new Marriage Law of 1950 aimed to liberate women from a feudal Confucian-patriarchal tradition by letting them choose their own spouses and stopping concubinage and mercenary marriages. However, the promotion of free choice marriage, when combined with the importance placed in Chinese culture on marriage for procreation and the establishment of a state-controlled media, literally eliminated the space for public discussions of sexual orientation and identity until the 1990s.

The Criminal Law of the People's Republic of China, which was first issued in 1979 and then revised in 1997, does not directly criminalize homosexuality. It prohibits non-consensual sex acts such as rape, sexual assault, forced prostitution and sex with minors (Criminal Law of the People's Republic of China 1997, Articles 237-8 and 358). The age of consent for sexual activity is 14 years, with no restrictions on gender or sexual orientation. But the Law criminalizes as harmful some activities that may limit freedom of sexual expression, including the third-party organization of prostitution and orgies, and the manufacture and dissemination of pornography (Sections 8-9 and Article 301). Before 1997, homosexuals were sometimes detained by police for engaging in acts of "hooliganism" based on a 1984 ruling by the Supreme People's Court. To the extent that police targeted homosexuals, they tended to police the public spaces that men who have sex with men were known to frequent to find sexual partners and engage in sex acts, such as toilet blocks and parks (Li 2009, 86-7).

The establishment of support organizations for LGBT people was also restricted by state authorities in the 1990s, as demonstrated by the case of Wan Yanhai. In late 1992, Wan $(2001,60)$ organized a salon called "Men's World," a health promotion group for same-sex attracted men, which held a Valentine's Day celebration in 1993. While encouraging similar gatherings in other cities, the salon was promptly closed down. The Ministry of Public Security issued a document about this decision, titled Notice on the Closure of the "Men's World" Homosexual Culture Salon (Gonganbu 1993). The Notice stated that the salon had been closed down at the request of the Ministry of Health because of public complaints. Illustrating a highly negative view of homosexuality, the Notice stated that homosexuality was a perverse form of human behaviour that violated public morality, corrupted social 
Elaine Jeffreys and Pan Wang (2018) 'Pathways to Legalizing Same-Sex Marriage in China and Taiwan: Globalization and "Chinese Values', in B. Winter, M. Forest and R. Sénac (eds), Global Perspectives on Same-Sex Marriage: A Neo-Institutional Approach, Cham: Palgrave Macmillan, pp. 197-220. Author Copy, 28 August 2017.

values, destroyed family harmony, encouraged criminality, endangered public security, and contributed to the spread of AIDS. While noting that such gatherings did not comprise a form of hooliganism, it concluded that similar homosexual gatherings could be investigated and closed down as "unlawful assemblies."

Homosexuality was also defined medically in terms of sexual dysfunction and mental disorder until 2001. It was defined as a psychosexual disorder in a 1981 clinical guide for the diagnosis of mental disorders published by the Chinese Society of Psychiatry. That text was retrospectively titled the first Chinese Classification of Mental Disorders in 1989, when it was replaced by the official second Chinese Classification of Mental Disorders. The description of homosexuality in terms of mental disorder was not removed from the Chinese Classification of Mental Disorders until it was revised again in 2001 (Chinese Society of Psychiatry 2001). It is worth noting that the World Health Organization (1992) only removed homosexuality from its classification of mental and behaviour disorders at the Forty-Third World Health Assembly in 1990, with a new International Classification of Diseases coming into effect in member states in 1994. Hence, the PRC's redefinition of homosexuality followed from the eventual adoption of international standards.

While the western LGBT movement developed through struggles against the pathologization of homosexuality, state controls over the PRC's media and civil sector have ensured that there are limited venues for organized advocacy on and positive self-presentations of LGBT issues. Regulations issued by the State Administration of Press, Publication, Radio, Film and Television in 2006 banned the inclusion of content relating to pornography, licentiousness, rape, commercial sex, sexual perversion, and sex organs ("Guojia guangbo dianying dianshi zongju ling” 2006, Article 14, Item 3). A 2008 notice on film and television censorship standards added homosexual sex to the list of banned sexual content. The continued potential for government censorship encourages self-censorship on the part of individuals and organizations both to avoid regulatory repercussions and to maintain commercial viability. Hence the majority of LGBT-themed media products and publications are independently produced and not widely circulated outside of LGBT circles (Jeffreys and Yu 2015, 82-4; UNDP and USAID 2014, 44-5). 
Elaine Jeffreys and Pan Wang (2018) 'Pathways to Legalizing Same-Sex Marriage in China and Taiwan: Globalization and "Chinese Values', in B. Winter, M. Forest and R. Sénac (eds), Global Perspectives on Same-Sex Marriage: A Neo-Institutional Approach, Cham: Palgrave Macmillan, pp. 197-220. Author Copy, 28 August 2017.

Yet some same-sex attracted people claim that the major problem faced by people in China who wish to live openly as LGBT is "not state oppression, religious fundamentalism, or job discrimination", but rather pressure from their relatives and peers (Chou 2001, 34). People of marrying age are pressured to get married to continue the family line and guarantee support for family elders. Data from the PRC's 2010 Population Census demonstrates that less than two per cent of men and women aged forty years and over had never married (Jeffreys and Yu 2015, 15). The now defunct one-child-per-couple policy has ensured that some parents and grandparents are prepared to accept the non-traditional sexual and lifestyle choices of their only child/grandchild in order to retain a relationship with them, but other parents place even more pressure on an only child to marry, reproduce, and otherwise lead a successful, "normal" life.

Many gays and lesbians view entering a heterosexual marriage as "the right thing to do" despite their sexual orientation, and others enter marriages of convenience to pass as straight to family members and work colleagues. In the words of one self-identified Chinese gay man who says he would consider marrying a woman to please his parents: "I am not ashamed of being gay at all. I only care about my family" (Lau 2010, see Wuhan - Robin's story). This situation has resulted in an estimated sixteen million heterosexual women being married unknowingly to same-sex attracted men (Jeffreys and Yu 2015, 39). Some homosexuals avoid or delay social pressures to marry by moving away from their place of birth and family home, and practising a classical Chinese aesthetic of "don't ask, don't tell" with their families and colleagues (Jeffreys and Yu 2015, 89). Others enter a "cooperative marriage", that is, a marriage between two homosexuals of the opposite sex who present themselves to family and work circles as a heterosexual couple, while maintaining separate gay and lesbian sex lives. The social networking site ChinaGayLes.com claimed to have had more than four hundred thousand registered users and assisted over 50,000 such marriages as of 2017 (www.chinagayles.com/).

But the space was opened for government action and domestic critique of government inaction on LGBT issues in December 2013, when the PRC government accepted recommendations at the Human Rights Council of the United Nations (UN) that it establish anti-discrimination legislation to ensure that LGBT people enjoy equal treatment (United 
Elaine Jeffreys and Pan Wang (2018) 'Pathways to Legalizing Same-Sex Marriage in China and Taiwan: Globalization and "Chinese Values', in B. Winter, M. Forest and R. Sénac (eds), Global Perspectives on Same-Sex Marriage: A Neo-Institutional Approach, Cham: Palgrave Macmillan, pp. 197-220. Author Copy, 28 August 2017.

Nations General Assembly 2013). In 2016, in an action described as the largest coordinated event in the history of China's LGBT movement, nearly two hundred organizations released a publicized letter condemning violence based on sexual orientation, after a gunman killed forty-nine people in a gay nightclub in Orlando, Florida in the USA in June of that year (Bai 2016). The letter added that Chinese LGBT people experience unacceptable violence and discrimination, as demonstrated by the existence of "gay conversion therapy" and schoolyard bullying of LGBT youth. This action followed media publicity on a series of landmark legal cases heard by the Chinese courts in 2015-2016, which criticized government inaction on social and workplace discrimination based on sexual orientation and gender identity, and demanded the introduction of affirmative legislation, including the legalization of same-sex marriage.

\section{Advocacy for same-sex marriage}

In 2015, Sun Wenlin filed a landmark case against a civil affairs department in Changsha City, Hunan Province, for refusing to register a marriage between him and his male partner, Hu Mingliang (Phillips 2016). The court's acceptance of the case in January 2016 attracted international publicity in the wake of the June 2015 US Supreme Court ruling, which ruled that individual states in the USA could not ban same-sex marriage without abrogating constitutional guarantees of due process and equal protection under the law. The US ruling generated widespread interest on Chinese social media, resulting in companies such as Taobao, an online shopping platform, placing the rainbow flag on their homepages. In April 2016, the Changsha court rejected Sun's claim that the PRC's Marriage Law is non-gender specific and affirmed that marriage can only take place between a man and a woman according to extant law (Phillips 2016). However, the court's acceptance of the case is viewed as a milestone in terms of LGBT affirmative action on civil rights. It highlights the potential to alter regulations related to the legal registration of marriages in China, which are administrative rather than celebratory or religious in nature.

Activists Li Yinhe and Lin Xianzhi have advocated for legal protections for same-sex couples not through the courts, but during the annual meetings of the National People's Congress and the Chinese People's Political Consultative Conference (CPPCC), which foreign analysts 
Elaine Jeffreys and Pan Wang (2018) 'Pathways to Legalizing Same-Sex Marriage in China and Taiwan: Globalization and “Chinese Values', in B. Winter, M. Forest and R. Sénac (eds), Global Perspectives on Same-Sex Marriage: A Neo-Institutional Approach, Cham: Palgrave Macmillan, pp. 197-220. Author Copy, 28 August 2017.

often jointly dismiss as a "rubber-stamp parliament." Li Yinhe is a famous sociologist and sexual rights' activist; her Sina.com blog alone had received more than one hundred million visitors by 2017 (http://blog.sina.com.cn/liyinhe; Jeffreys and Yu 2015, 162-8). Li unsuccessfully lobbied delegates at the CPPCC to consider a proposal on legalizing same-sex marriage on at least seven occasions between 2003 and 2016. In most instances, Li failed to find a delegate willing to present her proposal; on the few occasions when a delegate agreed to present her proposal it failed to obtain sufficient signatures to be placed on the official agenda for discussion. In 2013 and 2014, Liang Wenhui, a male social work student, also sent Li's proposal and an open letter signed by one hundred gay parents to NPC deputies petitioning for the legalization of same-sex marriage, after two lesbians attempted to register a marriage but failed. He has since founded a Guangzhou-based organization called the Gaystraight Alliance (http://rainrainbowcomeout.blog.163.com/).

Li Yinhe's proposal states that legalizing same-sex marriage will benefit Chinese society for six reasons (Li 2015). First, it will ensure that Chinese citizens enjoy equal rights. Second, it will reduce the spread of HIV by encouraging monogamy. Third, it will revive China's traditional cultural acceptance of same-sex eroticism. Fourth, it will build the PRC's international reputation as a promoter rather than violator of human rights. Fifth, it will reduce the number of "fake" and "cooperative" marriages. Finally, it will promote social harmony by preventing clashes between minority and mainstream groups. Despite failing to obtain formal political traction, Li's lobbying has attracted publicity and debate.

Li Yinhe obtained further news coverage in 2014-2015 when she announced on China's Twitter-like Weibo that her longstanding partner is a transman, and the People's Daily - the official mouthpiece of the CCP -responded to her revelations with support on its weibo. The People's Daily editor stated that homosexuality and transsexuality are increasingly accepted in Chinese society and that respecting one's personal views also means respecting "the choices of the Li Yinhe's among us" (Renmingwang weiping 2014). This response constitutes a rare example of the state-controlled media encouraging respect for sexual diversity. It suggests some degree of political support for raising awareness of LGBT issues and preventing expressions of homophobia. 
Elaine Jeffreys and Pan Wang (2018) 'Pathways to Legalizing Same-Sex Marriage in China and Taiwan: Globalization and "Chinese Values', in B. Winter, M. Forest and R. Sénac (eds), Global Perspectives on Same-Sex Marriage: A Neo-Institutional Approach, Cham: Palgrave Macmillan, pp. 197-220. Author Copy, 28 August 2017.

Lin Xianzhi, a retired government official, and member of PFLAG China, petitioned representatives at the NPC in 2015 to give young gay couples legal protections, while capitalizing on his son's temporary fame as a finalist in the Valentine's Day "Rainbow Love" contest hosted by Taobao (Doland 2015; Zhang 2015). Founded in 2008, PFLAG China has subgroups across the PRC (pflag.org.cn) and is an independent version of PFLAG (an acronym for Parents and Friends of Lesbians and Gays, an organization founded in the USA in the 1970s that now supports families and friends of LGBTIQ people). The competition featured as a rotating advertisement on the Taobao homepage through partnerships with the global marketing company China Luxury Advisors and three Chinese LGBT organizations Danlan.org (a gay website), PFLAG China and the Beijing LGBT Center. It offered ten same-sex Chinese couples an all-expenses paid trip to California to get married during a group wedding there, with funding from a bedding company. Taobao users voted on the finalists based on short videos of the couples telling their stories about how they met and fell in love, and why they wanted to marry. Over four hundred couples competed, one million people viewed the event page, and more than seventy-five thousand people voted.

Lin's actions draw attention to an unfamiliar convergence of parental, activist, and commercial concerns to promote marriage equality in the formal political context of the NPC. The couples who entered the Taobao-hosted competition were recruited through LGBT networks, and had the support of families and colleagues to compete, or else were unconcerned about the social consequences of having their images and love stories presented on social and broadcast media. Lin's son entered the competition as an "out" gay with a father who openly supports his son's right to live without discrimination as a member of PFLAG China. Lin petitioned the NPC as a CCP member and Chinese parent speaking for all parents who worry about the future security of their child, and especially when their child's sexual orientation affords them no legal protections vis-à-vis medical care, property purchase, and inheritance (Zhang 2015). Here, Lin used traditional conceptions of family obligations to argue for improved legal protections for people in homosexual relationships.

Taobao's use of advertising featuring same-sex couples demonstrates commercial interest in the potentially huge Chinese "pink market," although Taobao representatives emphasized that the contest aimed to increase "respect and understanding for homosexuality, and support the 
Elaine Jeffreys and Pan Wang (2018) 'Pathways to Legalizing Same-Sex Marriage in China and Taiwan: Globalization and “Chinese Values', in B. Winter, M. Forest and R. Sénac (eds), Global Perspectives on Same-Sex Marriage: A Neo-Institutional Approach, Cham: Palgrave Macmillan, pp. 197-220. Author Copy, 28 August 2017.

realization of dreams" (Doland 2015). Thus, as in other parts of the world, Chinese LGBT struggles for sexual citizenship may soon become entangled with commercial interests and consumer activities. This could expand the availability of LGBT-themed venues, products, and events, especially for members of younger generations. For example, Star-G Technologies is producing mobile games that target gay players ("gaymers"), with one game enabling players to select their images, clothing, and accessories, and also to network with other players and participate in virtual marriages (Shan 2016). Commercial interest could also generate alternative funding for LGBT events and activism via niche and cause-related marketing.

More recently, in February 2017, Sun Wenlin and Hu Mingliang - the men who went to the Chinese courts to protest their inability to register a same-sex marriage - launched the Family Equality Network, which is styled after the Taiwan Alliance to Promote Civil Partnership Rights (TAPCPR) (Pingdengjiatingwang 2017). The TAPCPR has played a major role in bringing a same-sex marriage bill before the Taiwan parliament and prompting local governments to permit the registration of same-sex civil partnerships (see below). Although the Taiwan bill is framed in terms of meeting international conventions on human rights, Sun and Hu's website also aims to build momentum for reform within the existing legal framework of the PRC.

Sun and $\mathrm{Hu}$ have launched the website to raise public awareness of marriage equality and obtain one million online signatures in support of legalizing same-sex marriage to present to the NPC. They hope that a large-scale expression of public support will oblige NPC deputies to amend the PRC's Marriage Law. They have therefore drafted and posted a gender-neutral version of that law online. This action seeks to benefit from the consultative legal approach first adopted by the PRC government in the early 2000s, when it asked for public comment on proposed amendments to the Marriage Law. It has since become common government practice to make draft laws and regulations available for public consultation before they are finalized and ratified. Sun and Hu's initiative thus represents an effort to jump-start government action on marriage equality by suggesting a similar need for public consultation. 
Elaine Jeffreys and Pan Wang (2018) 'Pathways to Legalizing Same-Sex Marriage in China and Taiwan: Globalization and "Chinese Values', in B. Winter, M. Forest and R. Sénac (eds), Global Perspectives on Same-Sex Marriage: A Neo-Institutional Approach, Cham: Palgrave Macmillan, pp. 197-220. Author Copy, 28 August 2017.

Although Sun and Hu's efforts represent a further step towards a same-sex marriage 'movement' in the PRC, they have attracted limited public and government attention to date and their capacity to galvanize broad support remains uncertain. Six months after the launch of the Family Equality Network, the marriage equality petition had obtained just over seven thousand online signatures. It remains to be seen whether the Taiwan Constitutional Court ruling will give impetus to public debate and action on same-sex marriage in China.

\section{Case Study 2: Taiwan}

What has led the Taiwan government to go so much further down the path towards recognizing same-sex marriage? Domestic pressure from an active LGBT movement is a popular answer. Taiwan is described as "the most LGBT-friendly country in Asia" (Lee 2016, 987), with tens of thousands of people attending annual pride events (Jennings 2016).

Activist Chi Chia-wei first and unsuccessfully petitioned the Constitutional Court to rule on same-sex marriage in 2001 ("Victory at last" 2017). In 2015, with legal support from the TAPCPR, Chi requested a Constitutional Court ruling on Article 972 of Taiwan's Civil Code, which states that a marriage is between a man and woman. Another request was filed that same year by the Taipei City government, "after three same-sex couples lodged an administrative lawsuit against the government when their marriage registrations were rejected" (Hunt and Tsui 2017). In May 2017, the court ruled that Article 972 violates constitutional rights to equality and gave the Taiwan parliament two years to amend or enact laws.

A second answer is party politics. The Democratic Progressive Party (DPP), which first took over government in 2000, ending fifty-odd years of Nationalist Party rule, has developed a strong political identity as a party that is committed to realizing an economically prosperous, cosmopolitan, liberal, and independent Taiwan. The DPP is a member of Liberal International, a founding member of the Council of Asian Liberals and Democrats and has represented Taiwan at numerous related international forums. Its leading members are also relatively young and often overseas-trained professionals. As such, the DPP has supported lobbying by domestic gender and LGBT organizations, including demands for marriage equality. 
Elaine Jeffreys and Pan Wang (2018) 'Pathways to Legalizing Same-Sex Marriage in China and Taiwan: Globalization and "Chinese Values', in B. Winter, M. Forest and R. Sénac (eds), Global Perspectives on Same-Sex Marriage: A Neo-Institutional Approach, Cham: Palgrave Macmillan, pp. 197-220. Author Copy, 28 August 2017.

A third and related answer is the DPP's goal of obtaining international recognition for an independent Taiwan. In 2013, the year of the PRC's second UN human rights review, the Taiwan government organized its first human rights' review committees and welcomed UN experts to review its human rights reports. The committees' recommendations on LGBT issues are now considered by NGOs when monitoring law and policies (Lee 2016, 982).

Hence, the combination of an active LGBT movement and the DPP's political strategizing vis-à-vis the PRC and the Nationalist Party - the original members of which were mainland Chinese - have left Taiwan well-placed to become the first country in Asia to legalize samesex marriage. Leading DPP representatives have stated that: "if Taiwan can get this [legislation] passed ... it will give other Asian countries a model" (Jennings 2016). An article in The Economist underscores the political subtext of differentiating a democratic Taiwan from the authoritarian PRC by stating: "it would be even better if the country that hardly any others recognize became the first in Asia to recognize that gay people deserve equality" ("Taiwan debates gay marriage" 2016).

\section{Background}

In an article titled "Same sex desire and society in Taiwan, 1970-1987", Jens Damm (2005, 68) states that: "Taiwanese society between the 1950s and 1960s could be described as heterosexualized in terms of discourse; 'family values' were regarded as deriving directly from a stable Confucian and Chinese tradition and public discourses of same-sex desire were almost non-existent.” That tradition emphasized filial piety, respect for authority and adherence to social norms. Historically, as in China, this meant that a sexual encounter between two people of the same sex was neither immoral nor violated the Confucian ethical system so long as an individual respected familial obligations to continue the paternal family line.

During the 1970s and 1980s, the subject of homosexuality became associated with abnormality, deviancy, disease, and immorality, although some activists contested such views. Same-sex desire was pathologized as a form of mental illness via the introduction of western medical discourses in the 1970s (Damm 2005, 71), as it was in the PRC during the 1980s. 
Elaine Jeffreys and Pan Wang (2018) 'Pathways to Legalizing Same-Sex Marriage in China and Taiwan: Globalization and "Chinese Values', in B. Winter, M. Forest and R. Sénac (eds), Global Perspectives on Same-Sex Marriage: A Neo-Institutional Approach, Cham: Palgrave Macmillan, pp. 197-220. Author Copy, 28 August 2017.

Although some academics argued that homosexuality was a minority rather than abnormal sexual practice, the first media reports to mention same-sex desire were about police arrests of homosexuals in parks and couched in terms of deviancy (Damm 2005, 72-3 \& 75), which is also similar to the PRC experience. By the mid-1980s, when Taiwan's first case of AIDS was identified, numerous articles appeared in which AIDS was linked to "the problem of homosexuality," and AIDS was presented as a "foreign" disease associated with "western" behaviours such as sexual promiscuity (Damm 2005, 80). Again, this is not too dissimilar to events in the PRC.

However, the end of Martial Law in 1987 is generally viewed as a watershed in terms of enabling the development of a civil society in Taiwan, and subsequently active LGBT organization, although some individual activism occurred earlier. In 1983, Hsien-yung Pai published a bestselling novel, Crystal Boys, about the lives of socially ostracized, young gay men (Cheng, Wu and Adamczyk 2016, 321). Activist Chi Chia-wei filed an unsuccessful case with the District Court of Taipei to marry his same-sex partner that same year. Confirming the then-dominant negative views of homosexuality, the case was rejected on the grounds that homosexuality was abnormal and immoral, and therefore gay marriage should not be permitted (Cheng, Wu and Adamczyk 2016, 321).

Taiwan's first gay and lesbian organizations were established in the 1990s. The first lesbian group, "Between Us", was founded in 1990; two student societies for gays and lesbians respectively were set up at National Taiwan University in the mid-1990s; and two gayfriendly religious organizations, the Tong-Kwang Light House Presbyterian Church and the Buddhist group “Tong Fan Jing Sheh” were established in 1996 (Cheng, Wu and Adamczyk 2016, 321). The first formally registered gay activist group, the Taiwan Tongzhi Hotline Association, was registered in 1998; and Taiwan's first annual Pride parade was held in 2003. The Taiwan Alliance to Promote Civil Partnership Rights was founded in late 2009 by the feminist Awakening Foundation, the Taiwan Tongzhi Hotline Association and the TongKwang Light House Presbyterian Church, among other organizations, and was joined by the Taiwan Adolescent Association on Sexualities in 2011 (tapcpr.org). However, as in the PRC, the cultural emphasis on social and familial harmony has ensured that many gays and lesbians 
Elaine Jeffreys and Pan Wang (2018) 'Pathways to Legalizing Same-Sex Marriage in China and Taiwan: Globalization and "Chinese Values', in B. Winter, M. Forest and R. Sénac (eds), Global Perspectives on Same-Sex Marriage: A Neo-Institutional Approach, Cham: Palgrave Macmillan, pp. 197-220. Author Copy, 28 August 2017.

prefer to stay "invisible," or "hide in the closet," rather than engage in the potentially conflictual act of "coming out" (Lee 2016, 986; Wang, Bih and Brennan 2009, 287).

During the administration of Chen Shui-bian (2000-2008), the first president of the Republic of China from a political party other than the Nationalist Party, "an advisory panel was established under the Presidential Office to suggest amendments to Taiwan's human rights law" (Melnik 2016, online). The DPP-led government has variously sought to obtain political support for Taiwanese independence from the international community, and to differentiate itself from China, by "ratifying” UN multilateral human rights treaties (Lee 2016, 980). In 2009, the Taiwan parliament "ratified" international covenants on civil and political rights, and on economic, social, and cultural rights, and attempted unsuccessfully to deposit instruments of ratification at the UN. This attempt was unsuccessful because Taiwan is not a member of the UN; the UN recognizes the PRC as the sole and legitimate representative of China. However, in 2013, the Taiwan government organized its own first human rights' review committees and welcomed UN experts to review its human rights reports. The experts' recommendations included acceptance of a 2012 report by the TAPCPR which stated that Taiwan's failure to recognize diverse families and same-sex marriage ran counter to the UN Convention on the Elimination of all Forms of Discrimination Against Women (TAPCPR 2014).

Consensual, adult same-sex sexual activity is not criminalized in Taiwan, the age of consent is sixteen years irrespective of gender, and according to the Taiwan 2013 Human Rights Report the country has implemented LGBT anti-discriminatory measures. Although the Constitution does not refer to sexual orientation or gender identity, the Taiwan 2013 Human Rights Report interpreted the Constitution as prohibiting discrimination based on race, gender, disability, language, sexual orientation, gender identity, and social status. Employment service laws were passed in 2007 that prohibited social and workplace discrimination based on sexual orientation or gender identity. In 2010, the Ministry of Education also announced that primary school textbooks would include topics on LGBT rights and anti-discrimination (Lee 2016, 980). The Taiwan 2013 Human Rights Report referred to marriage as being between a man and a woman in the context of bans on early and forced marriage (United States Department of State, Bureau of Democracy, Human Rights and Labor 2013). However, 
Elaine Jeffreys and Pan Wang (2018) 'Pathways to Legalizing Same-Sex Marriage in China and Taiwan: Globalization and "Chinese Values', in B. Winter, M. Forest and R. Sénac (eds), Global Perspectives on Same-Sex Marriage: A Neo-Institutional Approach, Cham: Palgrave Macmillan, pp. 197-220. Author Copy, 28 August 2017.

arguments in favour of recognizing same-sex unions increasingly emerged as a feature of public life and debate in Taiwan from the early 2000s onwards.

\section{Advocacy for same-sex marriage}

Between 2003 and 2017, a series of proposals were brought before the Taiwan parliament in support of marriage equality. A failed proposal in 2003 recommended that people have the right to marry and form families according to their free will. In 2005, a member of the DPP proposed a bill to legalize same-sex marriage, which was blocked immediately upon submission. In 2012, the TAPCPR released the Draft Revisions to the Civil Code for the Recognition of Families of Diversity, which recommended legalizing same-sex marriage by amending the Civil Code to make the sections dealing with marriage and family genderneutral, and included new provisions for civil partnerships and multiple-person families. In 2013, DPP members proposed amending the Civil Code to make the chapter on marriage gender-neutral, thereby institutionalizing marriage equality and gay adoption. The proposal was also presented to the Judiciary Committee of the Taiwan parliament in late 2014, but was not discussed (Lee 2016, 981). By 2016, all of Taiwan's major political parties had publicized bills on same-sex marriage (Legislative Council Proceedings 2016a, 2016b). In 2016, a bill proposed by DPP legislator Yu Mei-nu, former Chair of the Awakening Foundation, was read in parliament.

Even prior to the May 2017 Constitutional Court ruling that labelled laws preventing samesex marriage as unconstitutional, the 2016 same-sex marriage bill was generally expected to result in legislation by mid to late 2017, with the timing subject to further cross-party negotiation. The passing of the bill in 2016 had been stalled by debate over whether oppositesex and same-sex marriages should be differentiated in law. Instead of replacing the words "male and female parties" in the Civil Code's marriage chapter with "two parties," the amendments demanded of the bill proposed adding that "an agreement to marry shall be made by the male and female parties in their own accord," and "an agreement to marry in a same-sex marriage, shall be made by the two parties in their own accord" (Sun 2016). The amendments also guaranteed an equal application of parental rights to same-sex couples by amending Article 1079-1 - the clause governing adoptions - to prohibit a court from rejecting 
Elaine Jeffreys and Pan Wang (2018) 'Pathways to Legalizing Same-Sex Marriage in China and Taiwan: Globalization and "Chinese Values', in B. Winter, M. Forest and R. Sénac (eds), Global Perspectives on Same-Sex Marriage: A Neo-Institutional Approach, Cham: Palgrave Macmillan, pp. 197-220. Author Copy, 28 August 2017.

an application to adopt on the basis of the applicants' sexual orientation. Given the significant imprimatur provided by the Constitutional Court, there are reasonable prospects that the bill will be passed in its current form. By the same token, the process of institutionalizing samesex marriage could be slowed if additional discussion is required in the parliament to agree on the precise details of the legislation.

Alongside the growing impetus towards same-sex marriage legislation that was playing out in the national legislature, and in anticipation of eventual changes in the law, city governments contemporaneously introduced a system of same-sex partnership registration between 2015 and 2016, with the aim of respecting gender equality and human rights ("All Taiwan municipalities to recognize same-sex relationships" 2016). The city of Kaohsiung, led by Mayor Chen Chu, President of the Taiwan Association for Human Rights, became the first city to allow same-sex couples to register their partnership as part of household registration in March 2015. The household registration system records where individuals live and operates as a citizen identification system, with up-to-date registration required to obtain citizen ID cards and thus to open bank accounts and obtain passports, and so on. By March 2016, all of Taiwan's city governments had followed suit; around seventy-five per cent of Taiwan's population live in these jurisdictions (Melnik 2016).

In practice, the decision to allow same-sex partnerships to be registered through the household registration system established a civil precedent for legalizing same-sex marriage, prompting LGBT activist groups to urge the central government to pass legislation immediately (Chang 2016). A certificate of partnership household registration is not equivalent to a marriage certificate and offers fewer legal protections in comparison. However, it allows registered partners to sign medical contracts for each other and can be used as evidence of partnership in some legal disputes. Around two thousand same-sex couples had registered partnerships by the end of 2016 (Chou 2017).

These developments were encouraged by numerous actions organized by the TAPCPR. In late 2012, the TAPCPR launched a petition to collect one million signatures within one year to present to the Taiwan parliament in support of LGBT rights to marry. Popstar A-Mei was the first to sign, followed by other entertainment celebrities. A-Mei and around forty other 
Elaine Jeffreys and Pan Wang (2018) 'Pathways to Legalizing Same-Sex Marriage in China and Taiwan: Globalization and "Chinese Values', in B. Winter, M. Forest and R. Sénac (eds), Global Perspectives on Same-Sex Marriage: A Neo-Institutional Approach, Cham: Palgrave Macmillan, pp. 197-220. Author Copy, 28 August 2017.

artists also held a concert in 2016 to raise funds for the TAPCPR named "Love is King: it makes us all equal." The ten thousand tickets were reportedly sold only one minute after they went on sale (Chang 2016). Yet the TAPCPR's year-long petition only obtained just over one hundred thousand rather than one million signatures. By comparison, a petition opposing same-sex marriage launched in 2013 by the Alliance of Taiwan Religious Groups for the Protection of Family obtained close to seven hundred thousand signatures ("Taiwan duoyuan chengjia fa'an jianjie" 2013).

The TAPCPR endorsed Tsai Ing-wen's failed bid for presidential election as the leader of the DPP in 2012 and her successful bid in 2016. Tsai's position as leader of the DPP is considered unusual because she is female, single, and of aboriginal Taiwanese rather than Chinese descent. Tsai had supported arguments in favour of same-sex marriage although not systematically. In October 2015, a year before her election as the first female President of Taiwan, she campaigned on freedom of love and expressed her support for marriage equality in a video posted on Facebook around the time of the country's LGBT pride march. Tsai (2015) declared: "I support marriage equality. Everyone has the right to pursue their own love and happiness."

A groundswell of popular support for same-sex marriage was also evident in the run-up to the December 2016 parliamentary hearing of the bill on marriage equality, following the suicide, in October, of a gay professor, Jacques Picoux, reportedly due to the absence of legal protections for same-sex couples (Kingston 2016). Picoux suffered depression after he was prevented from participating in end-of-life medical decisions regarding his partner of more than thirty-five years. His Taiwanese partner's family then disputed his property and inheritance rights.

Tens of thousands of people also gathered outside the Taiwan parliament to protest against marriage equality. According to media reports, the protests had a strong "Christian flavour," and involved clergy and members of groups such as the Protect the Family Alliance and the Happiness of the Next Generation Alliance, drawing upon similar arguments to those that inform North American conservative religious groups and possibly enjoying assistance from such groups (Cole 2016, 2017). The Happiness of the Next Generation Alliance encouraged 
Elaine Jeffreys and Pan Wang (2018) 'Pathways to Legalizing Same-Sex Marriage in China and Taiwan: Globalization and "Chinese Values', in B. Winter, M. Forest and R. Sénac (eds), Global Perspectives on Same-Sex Marriage: A Neo-Institutional Approach, Cham: Palgrave Macmillan, pp. 197-220. Author Copy, 28 August 2017.

around two hundred thousand people in the cities of Taipei, Taichung, and Kaohsiung, to protest against same-sex education in schools and the legalization of same-sex marriage, with some protestors reacting violently to people holding banners in support of anti-discrimination and marriage equality.

As this suggests, the legalization of same-sex marriage and adoption have proven to be potentially divisive topics in Taiwan politics and society. Although Christians comprise just over seven per cent of Taiwan's population, many are actively opposed to marriage equality. A standard argument against same-sex marriage is that legalization will undermine traditional Chinese family values, which emphasize heterosexual marriage for the purposes of reproduction (Wang, Bih and Brennan 2009, 285). The Protect the Family Alliance further argues that legalization is not in the national interest because it will involve large administrative and legislative resources, cause social and political instability, undermine the rights of children, and contribute to Taiwan's already low birth rate and growing prevalence of HIV infection ("Taiwan shouhu jiating" 2016).

These shows of public support and protests prompted some Nationalist Party members to call on President Tsai Ing-wen to resign, to which the Presidential Office responded that she would meet with groups that support and oppose marriage equality (Sun 2016). Despite these overtures towards a consensus-building agenda on same-sex marriage on the part of the DPP, the marriage equality campaign now appears to have the ascendancy. Following the 2017 Constitutional Court ruling, the passing of a bill such as that proposed by Yu Mei-nu appears to be assured. However, the process of entering it into law could be protracted depending on the extent of discussion required in the parliament to agree on the details of the legislation.

\section{Conclusions}

Taiwan looks likely to become the first country in Asia to legalize same-sex marriage, probably through acceptance of a parliamentary bill. An active LGBT movement has developed rapidly in Taiwan since the 1990s in the context of political and social liberalization, and political party strategizing for a democratic and independent Taiwan. However, Taiwanese society is split on the subject of same-sex marriage, with opponents 
Elaine Jeffreys and Pan Wang (2018) 'Pathways to Legalizing Same-Sex Marriage in China and Taiwan: Globalization and “Chinese Values', in B. Winter, M. Forest and R. Sénac (eds), Global Perspectives on Same-Sex Marriage: A Neo-Institutional Approach, Cham: Palgrave Macmillan, pp. 197-220. Author Copy, 28 August 2017.

claiming that it will undermine traditional Chinese and Christian family values. Hence, the future governmental support of LGBT couples and families may depend in part on how the major political parties strategize to win domestic votes. It may also depend on Taiwan's efforts to gain recognition in international arenas for their strong support of civil and human rights vis-à-vis the PRC.

Hildebrandt (2011) contended that a political decision on same-sex marriage in the PRC, driven by its foreign policy strategy and uninformed by activism and international pressure, represented the primary avenue for progress on the issue. Yet it can be argued that louder domestic public advocacy more recently, the formal acceptance of UN proposals to progress anti-discrimination legislation, and the striking ruling in Taiwan, combine to increase the tacit pressure on the PRC Government to act on marriage equality. While the PRC Government is unlikely to follow the ruling of the Taiwan Constitutional court with a similar pronouncement of its own in short order, the ruling will undoubtedly foster public debate on same-sex marriage, rule of law, and human rights, in the PRC. The odds of such a debate eventually leading to regulatory or legislative changes are improved by the fact that the history of government in the PRC has removed some of the obstacles to legalizing same-sex marriage that have emerged in Taiwan, most notably oppositional political, social, and religious groups, and to some extent Confucian family structures.

Although some commentators view China's Confucian tradition as a stand-in for religion in terms of discouraging homosexuality, that tradition has been transformed by the history and praxis of PRC socialism. Moreover, historically, same-sex eroticism was tolerated as long as it did not interfere with family and kinship obligations to continue the male line (Hildebrandt 2011). The nature of the "traditional Chinese family" has since been radically altered by the impact of the 1950 Marriage Law, Cultural-revolution-era injunctions for young people to attack tradition, the one-child-per-couple policy, and economic reforms and associated population mobility. The fact that the PRC government is currently promoting filial piety to meet the demands of aged care demonstrates the frail if evocative nature of that tradition. In fact, the Confucian "tradition" has been reinvented via major government advertising on citizenship and civic behaviours in recent years to promote what are described as core "Chinese" and "socialist" values such as democracy, civility, harmony, freedom, equality, 
Elaine Jeffreys and Pan Wang (2018) 'Pathways to Legalizing Same-Sex Marriage in China and Taiwan: Globalization and “Chinese Values', in B. Winter, M. Forest and R. Sénac (eds), Global Perspectives on Same-Sex Marriage: A Neo-Institutional Approach, Cham: Palgrave Macmillan, pp. 197-220. Author Copy, 28 August 2017.

justice, rule of law, and friendship. All of these values could be cited in support of marriage equality and in conjunction with or even instead of the discourse of human rights.

But the fledgling nature of struggles for LGBT rights in China has meant that domestic pressure for marriage equality is a recent and restrained phenomenon. Large-scale, coordinated advocacy on LGBT issues is limited because government controls over the nonprofit sector have ensured that international NGOs working in the PRC usually maintain a non-antagonistic attitude towards government authorities to continue operating (Hildebrandt 2011). Domestic non-profits need good relationships with local governments to register as a non-profit and obtain funding, and hence are wary of working with international networks, unless they are government-approved. Additionally, although the number of Chinese LGBT organizations is increasing, they are small in number and weak in capacity. However, as demonstrated by the examples of Sun Wenlin, Hu Mingliang, Li Yinhe, Liang Wenhui, and Lin Xianzhi, the issue of marriage equality has been raised in the Chinese courts and in the political spaces surrounding the PRC's "parliament."

As recent domestic advocacy also suggests, the PRC government could use same-sex marriage legislation strategically to improve China's international reputation, while addressing domestic issues such as improving sexual health, supporting alternative family arrangements, and reducing the number of "fake" marriages, especially given the relatively low social and political risk of doing so. Legislation can be passed quickly by Party-state authorities without having to undergo prolonged parliamentary debate with different parties serving different constituencies (Hildebrant 2011). Marriage registration in the PRC is also an administrative rather than religious affair, and religious organizations are constrained by government controls.

The PRC government could therefore meet its 2013 UN agreement to ensure that LGBT people enjoy equal treatment by recognizing same-sex marriage through government fiat. Marriage equality could improve the situation of Chinese LGBT people by sending a strong message to government officials and the general public that homosexuality is legal and acceptable, and social and institutional discrimination is unacceptable. However, the adoption of such a strategy depends on government interest, which at the minimum presupposes 
Elaine Jeffreys and Pan Wang (2018) 'Pathways to Legalizing Same-Sex Marriage in China and Taiwan: Globalization and "Chinese Values', in B. Winter, M. Forest and R. Sénac (eds), Global Perspectives on Same-Sex Marriage: A Neo-Institutional Approach, Cham: Palgrave Macmillan, pp. 197-220. Author Copy, 28 August 2017.

evident benefits in terms of international diplomacy and guaranteed domestic support given the recent emphasis on public consultation in law formation.

Another option would be for the PRC government to follow the precedent set by Taiwan, prior to the Constitutional Court ruling, of permitting same-sex civil partnership registration through the household registration system, and then, if such a change were well received, presenting a draft law on marriage equality for public consultation. Permitting civil partnerships via the household registration system would have the advantage of increasing statistical coverage and visibility for the authorities with respect to a growing segment of the population. Such a move could hasten progress towards a "peaceful" recognition of marriage equality, presented in terms of defending China's government-endorsed "core values". Yet, as individuals are typically registered as part of an existing household by providing evidence of marriage or adoption, it is unclear how the government could allow same-sex partners to be registered without altering existing legislation or specifying new extra-legal forms of evidence. If such obstacles can be overcome, there may be hope for progress on more formal recognition of same-sex relationships in the PRC. But any pro-active government action in that direction may also mean the co-option of China's nascent LGBT movement into government and Party structures in advance of an independent LGBT movement being developed.

\section{References}

“All Taiwan municipalities to recognize same-sex relationships" 2016. TheNewsLens, 7 March. Available at: https://international.thenewslens.com/article/37637 (accessed 8 February 2017).

Bai, Tiantian 2016. "190 Chinese LGBT groups condemn Orlando club shooting.” Global Times, 14 June. Available at: http://www.globaltimes.cn/content/988160.shtml (accessed 8 February 2017).

Chang, Eddy 2016. "Taipei watcher: the call is loud and clear.” Taipei Times, 28 August, p. 8. 
Elaine Jeffreys and Pan Wang (2018) 'Pathways to Legalizing Same-Sex Marriage in China and Taiwan: Globalization and "Chinese Values', in B. Winter, M. Forest and R. Sénac (eds), Global Perspectives on Same-Sex Marriage: A Neo-Institutional Approach, Cham: Palgrave Macmillan, pp. 197-220. Author Copy, 28 August 2017.

Cheng, Alice Yen-hsin, Wu, Felice Fen-chieh, and Adamczyk, Amy (2016) "Changing attitudes toward homosexuality in Taiwan, 1995-2012." Chinese Sociological Review 48(4):317-45.

Chinese Society of Psychiatry 2001. Zhongguo jingshenzhang'ai fenlei yu zhenduan biaozhun disanban [Chinese Classification for Mental Disorders Version 3 (CCMD-3)]. Jinan: Shandong Kexuejishu Chubanshe.

Chou, Abigail 2017. 'Taiwan same-sex marriage debate heats up as possibility nears." The Asahi Shimbun, 6 January. Available at:

http://www.asahi.com/ajw/articles/AJ201701060024.html (accessed 11 February 2017).

Chou, Wah-shan 2001. "Homosexuality and the cultural politics of tongzhi in Chinese societies." Journal of Homosexuality 40(3-4):27-46.

Cole, J. Michael 2016. "Thousands protest as Taiwan inches closer to legalising same-sex marriage.” Hong Kong Free Press, 18 November. Available at:

https://www.hongkongfp.com/2016/11/18/thousands-protest-taiwan-inches-closer-legalisingsex-marriage/ (accessed 8 February 2017).

Cole, J. Michael 2017. "U.S. hate group MassResistance behind anti-LGBT activities in Taiwan." Taiwan Sentinel, 2 January. Available at: https://sentinel.tw/us-hate-group-antilgbt/ (accessed 30 March 2017).

Criminal Law of the People's Republic of China 1997. Available at: http://www.fmprc.gov.cn/ce/cgvienna/eng/dbtyw/jdwt/crimelaw/t209043.htm (accessed 22 January 2017).

Damm, Jens 2005. "Same sex desire and society in Taiwan, 1970-1987." The China Quarterly 181:67-81. 
Elaine Jeffreys and Pan Wang (2018) 'Pathways to Legalizing Same-Sex Marriage in China and Taiwan: Globalization and 'Chinese Values', in B. Winter, M. Forest and R. Sénac (eds), Global Perspectives on Same-Sex Marriage: A Neo-Institutional Approach, Cham: Palgrave Macmillan, pp. 197-220. Author Copy, 28 August 2017.

Doland, Angela 2015. "For Valentine's Day, Alibaba helps gay Chinese couples get married in the U.S.” AdvertisingAge, 12 February. Available at: http://adage.com/article/globalnews/alibaba-helps-chinese-gay-couples-married-u-s/297108/ (accessed 8 February 2017).

Gonganbu 1993. “Guanyu qudi tongxinglian wenhua shalong 'nanren de shijie' de qingkuang tongbao" [Notice on the closure of the "Men's World" homosexual culture salon], Gong tong zi [1993] 62 hao. Available at:

http://www.chinaacc.com/new/63\%2F71\%2F2006\%2F3\%2Fxu6735315913360023029-

0.htm (accessed 22 January 2017).

Guojia guangbo dianying dianshi zongju ling: di 52 hao [Order No. 52 of the State Administration of Radio, Film and Television] 2006. 'Dianying juben (genggai) bei'an, dianying pian guanli guiding" [Regulations for the administration of the records of screenplay (outline) and films], 3 April. Available at: http://www.sarft.gov.cn/art/2006/6/22/art_1583_26305.html (accessed 22 January 2017).

Hildebrandt, Timothy 2011. "Same-sex marriage in China? The strategic promulgation of a progressive policy and its impact on LGBT activism.” Review of International Studies $37: 1313-33$.

Hunt, Katie and Tsui, Karina 2017. "Taiwan is closer to being $1^{\text {st }}$ Asian place to allow samesex marriage.” CNN, 24 May. Available at: http://edition.cnn.com/2017/05/24/asia/taiwansame-sex-marriage/ (accessed 26 May 2017).

Jeffreys, Elaine and Yu, Haiqing 2015. Sex in China. Cambridge: Polity.

Jennings, Ralph 2016. "Taiwan set to legalize same-sex marriages, a first in Asia.” Associated Press, 10 November. Available at: http://bigstory.ap.org/article/e9c5b9c82abe4bc987f820aa104f2893/taiwan-set-legalize-samesex-marriages-first-asia (accessed 8 February 2017). 
Elaine Jeffreys and Pan Wang (2018) 'Pathways to Legalizing Same-Sex Marriage in China and Taiwan: Globalization and "Chinese Values', in B. Winter, M. Forest and R. Sénac (eds), Global Perspectives on Same-Sex Marriage: A Neo-Institutional Approach, Cham: Palgrave Macmillan, pp. 197-220. Author Copy, 28 August 2017.

Kingston, Jeff 2016. "Same-sex marriage sparks a 'culture war' in Taiwan." The Japan Times, 10 December. Available at:

http://www.japantimes.co.jp/opinion/2016/12/10/commentary/sex-marriage-sparks-culturewar-taiwan/\#.WKFC7Y24Zjp (accessed 13 February 2017).

Lau, Steffi 2010. "Homosexuality in China.” US-China Today, 10 March. Available at: http://www.uschina.usc.edu/article@usct?homosexuality_in_china_14740.aspx (accessed 8 February 2017).

Lee, Po-han 2016. "LGBT rights versus Asian values: de/reconstructing the universality of human rights." The International Journal of Human Rights 20(7):978-92.

Legislative Council Proceedings 2016a. Meeting 1150 Proposal 19706, 2 November. http://lci.ly.gov.tw/LyLCEW/agenda1/02/pdf/09/02/09/LCEWA01_090209_00020.pdf (accessed 13 February 2017).

Legislative Council Proceedings 2016b. Meeting 1150 Proposal 19730, 31 October. Available at: http://lci.ly.gov.tw/LyLCEW/agenda1/02/pdf/09/02/09/LCEWA01_090209_00011.pdf (accessed 11 February 2017).

Li, Yinhe 2009. "Regulating male same-sex relationships in the People's Republic of China." In Elaine Jeffreys ed. Sex and Sexuality in China. Abingdon: Routledge, 82-101.

Li, Yinhe 2015. "Zhongguo heshi pizhun tongxinghunyin" [When will China ratify same-sex marriage?], 27 June. Available at: http://blog.sina.com.cn/s/blog_473d53360102vub7.html (accessed 8 February 2017).

Melnik, Alexander 2016. "Being tongzhi: examining LGBT rights in Taiwan.” Taiwan Business Topics, 19 October. Available at: http://topics.amcham.com.tw/2016/10/tongzhiexamining-lgbt-rights-taiwan/ (accessed 8 February 2017). 
Elaine Jeffreys and Pan Wang (2018) 'Pathways to Legalizing Same-Sex Marriage in China and Taiwan: Globalization and 'Chinese Values', in B. Winter, M. Forest and R. Sénac (eds), Global Perspectives on Same-Sex Marriage: A Neo-Institutional Approach, Cham: Palgrave Macmillan, pp. 197-220. Author Copy, 28 August 2017.

Phillips, Tom 2016. "China court refuses to allow gay marriage in landmark case.” The Guardian, 13 April. Available at: https://www.theguardian.com/world/2016/apr/13/chinacourt-refuse-gay-marriage-landmark-case (accessed 8 February 2017).

Pingdengjiatingwang [Family Equality Network] 2017. Available at: http://pingjia.lgbt/zh/?tag=\%E4\%BA\%BA\%E5\%A4\%A7\%E4\%BB\%A3\%E8\%A1\%A8 (accessed 28 August 2017).

Renmingwang weiping [People's commentary] 2014. People.cn, 19 December. Available at: http://weibo.com/2286908003/BBAf1EJ7W?type=comment\#_rnd1464314720702 (accessed 27 May 2016).

Shan, Juan 2016. "Pink economy' set to soar as companies target LGBT community." China Daily, 1 December. Available at: http://www.chinadaily.com.cn/china/201612/01/content_27533401.htm (accessed 11 April 2017).

Sun, Hsin Hsuan 2016. "Same-sex marriage clears first hurdle.” The China Post, 27 December. Available at: http://www.chinapost.com.tw/taiwan/national/nationalnews/2016/12/27/487771/Same-sex-marriage.htm (accessed 9 February 2017).

“Taiwan duoyuan chengjia fa'an jianjie.” 2013. Hong Kong Sex Culture Society 1:5-6.

“Taiwan debates gay marriage." 2016. The Economist, 3 December. Available at: http://www.economist.com/news/asia/21711096-it-would-be-first-country-asia-legalise-ittaiwan-debates-gay-marriage (accessed 13 February 2017).

“Taiwan shouhu jiating" [Protect the Family Alliance] 2016. Available at: https://taiwanfamily.com/related-posts/artice02_(accessed 8 February 2017).

TAPCPR 2014. Shadow Report on the Convention on the Elimination of All Forms of Discrimination Against Women. Available at: 
Elaine Jeffreys and Pan Wang (2018) 'Pathways to Legalizing Same-Sex Marriage in China and Taiwan: Globalization and 'Chinese Values', in B. Winter, M. Forest and R. Sénac (eds), Global Perspectives on Same-Sex Marriage: A Neo-Institutional Approach, Cham: Palgrave Macmillan, pp. 197-220. Author Copy, 28 August 2017.

https://tapcpr.files.wordpress.com/2014/04/cedaw-shadow-report-20140430.pdf (accessed 13 February 2017).

Tsai, Ing-wen 2015. Facebook, 30 October. Available at:

https://www.facebook.com/tsaiingwen/videos/10152991551061065/ (accessed 8 February 2017).

UNDP and USAID 2014. Being LGBT in Asia: China Country Report. Bangkok.

United Nations General Assembly 2013. Human Rights Council Twenty-fifth Session Agenda Item 6: Universal Periodic Review, Report of the Working Group on the Universal Periodic Review, China (including Hong Kong, China and Macao, China), 4 December.

United States Department of State, Bureau of Democracy, Human Rights and Labor 2013. Country Reports on Human Rights Practices for 2013: The Taiwan 2013 Human Rights Report. Available at: https://www.state.gov/documents/organization/220444.pdf (accessed 8 February 2017).

"Victory at last for Taiwan's veteran gay rights champion Chi Chia-wei." 2017. The Straits Times, 25 May. Available at: http://www.straitstimes.com/asia/east-asia/victory-at-last-fortaiwans-veteran-gay-rights-champion-chi-chia-wei (accessed 26 May 2017).

Wan, Yanhai 2001. "Becoming a gay activist in contemporary China." Journal of Homosexuality 40(3):47-64.

Wang, Frank, Bih, Herng-Dar, and Brennan, David 2009. "Have they really come out: gay men and their parents in Taiwan." Culture, Health \& Sexuality 11(3):285-96.

World Health Organization 1992. The ICD-10 Classification of Mental and Behavioural Disorders - Clinical Descriptions and Diagnostic Guidelines, Geneva: World Health Organization. 
Elaine Jeffreys and Pan Wang (2018) 'Pathways to Legalizing Same-Sex Marriage in China and Taiwan: Globalization and 'Chinese Values', in B. Winter, M. Forest and R. Sénac (eds), Global Perspectives on Same-Sex Marriage: A Neo-Institutional Approach, Cham: Palgrave Macmillan, pp. 197-220. Author Copy, 28 August 2017.

Yang, Zhuihui 2016. "Hunyin pingquan minfa xiuzheng cao'an liyuan chushen tongguo" [Taiwan parliament passes draft amendment to the Civil Law on marriage equality], Liberty Times Net, 26 December, Available at:

http://news.ltn.com.tw/news/politics/breakingnews/1928582 (accessed 11 February 2017).

Zhang, Yiqian 2015. "Gay marriage advocates ask legislators to present their proposals at the two sessions." Global Times, 16 March. Available at:

http://www.globaltimes.cn/content/912260.shtml (accessed 22 January 2017). 